OPEN ACCESS

Edited by:

Seema Arora-Jonsson, Swedish University of Agricultural

Sciences, Sweden

Reviewed by:

Harry W. Fischer,

Swedish University of Agricultural

Sciences, Sweden

Robert M. Mbeche,

Jomo Kenyatta University of

Agriculture and Technology, Kenya

${ }^{*}$ Correspondence:

Irene Leonardell

i.leonardelli@un-ihe.org

Specialty section:

This article was submitted to

Political Ecology,

a section of the journal

Frontiers in Human Dynamics

Received: 15 January 2021

Accepted: 22 March 2021

Published: 15 April 2021

Citation:

Leonardelli I, Bossenbroek L, Ftouhi H, Kadiri Z, Bhat S, Kulkarni S,

Hamamouche MF, Saidani MA

Zwarteveen $M$ and

Kemerink-Seyoum JS (2021)

COVID-19 in Rural India, Algeria, and

Morocco: A Feminist Analysis of

Small-Scale Farmers' and Agricultural

Laborers' Experiences and Inventive

Practices.

Front. Hum. Dyn. 3:653979. doi: 10.3389/fhumd.2021.653979

\section{COVID-19 in Rural India, Algeria, and Morocco: A Feminist Analysis of Small-Scale Farmers' and Agricultural Laborers' Experiences and Inventive Practices}

\author{
Irene Leonardelli ${ }^{1,2 *}$, Lisa Bossenbroek ${ }^{3}$, Hind Ftouhi ${ }^{4}$, Zakaria Kadiri ${ }^{5}$, Sneha Bhat ${ }^{6}$, \\ Seema Kulkarni ${ }^{6}$, Meriem Farah Hamamouche ${ }^{7,8}$, Mohamed Amine Saidani ${ }^{4,7,8,9}$, \\ Margreet Zwarteveen ${ }^{1,2}$ and Jeltsje Sanne Kemerink-Seyoum ${ }^{1,2}$ \\ ${ }^{1}$ Water Governance Department, IHE Delft Institute for Water Education, Delft, Netherlands, ${ }^{2}$ Governance and Inclusive \\ Development Group, Amsterdam Institute of Social Science Research, University of Amsterdam, Amsterdam, Netherlands, \\ ${ }^{3}$ iES Landau, Institute for Environmental Sciences, University of Koblenz-Landau, Landau, Germany, ${ }^{4}$ Département des \\ Sciences Humaines, Institute of Agronomic and Veterinary Institute Hassan II, Rabat, Morocco, ${ }^{5}$ Faculty of Arts and \\ Humanities Ain-Chock, University Hassan II, Casablanca, Morocco, ${ }^{6}$ Society for Promoting Participative Ecosystem \\ Management (SOPPECOM), Pune, India, ${ }^{7}$ Bureau d'Etudes, Consulting dans le domaine Agricole (ECA), Algiers, Algeria, \\ ${ }^{8}$ Joint Research Unit "Water Management, Actors, Territories" (UMR G-Eau), CIRAD, Montpellier, France, ${ }^{9}$ Montpellier \\ SupAgro, Montpellier, France
}

In this paper we present a situated analysis of the implications of the COVID-19 pandemic on the life of small-scale farmers and agricultural laborers in India, Algeria, and Morocco. We draw on data collected through phone interviews since April 2020. Inspired by feminist scholars, we analyze our findings thinking with - and entangling - the concepts of intersectionality, resilience and care. We firstly document the material impacts of the lockdown measures, focusing particularly on the experiences of single women farmers and laborers, whose livelihood and well-being have been notably compromised. Secondly, we unfold how different agricultural actors have come up with inventive ways to respond to the unexpected situation which they are facing. In doing so, we highlight the importance of considering the multiple and entangled socionatural challenges, uncertainties, and marginalizations that different agricultural actors experience, as well as the transformative potential of their inventive practices, which are often motivated and informed by notions of care.

Keywords: COVID-19, small-scale agriculture, intersectionality, resilience, care, India, Morocco, Algeria

\section{INTRODUCTION}

In March 2020, when lockdown measures were announced in many countries across the world, people were urged, if not obliged, to stay home and keep distance from each other in an attempt to slow the spread of COVID-19. Many businesses, local shops and markets had to temporarily close and national and international transportation was almost completely halted. We too, the authors of this paper, all of a sudden had to put our fieldwork in rural areas of Algeria, India, and Morocco on hold and in some cases be repatriated. 
We work in different agrarian contexts, where we analyze processes of agrarian change from a feminist critical perspective. It felt somehow sad and surreal to leave the places where we conduct our empirical research, particularly because we knew about the many challenges that the small-scale farmers and the agricultural laborers ${ }^{1}$ we regularly spent time with were facing both because of the COVID-19 health threat itself and because of the implications of the lockdown measures. The situation prompted new, sometimes troubling questions. It, for instance, made us painfully aware of how we are very differently affected by the pandemic than the farmers and laborers whom we study (with). After all, for us it was relatively easy to work from home and we would still receive our salaries. Those who depend on farming to make a living faced more challenges: when local markets are closed, where are they supposed to sell their produce? And if agricultural laborers cannot travel to their workplaces, how can they continue to sustain themselves and their families? How are they dealing with this situation? How have they reinvented the everyday organization of their livelihoods in these troubled times? In other words: what are the short-term implications of the pandemic for the farming practices and livelihoods of people relying on small-scale agriculture?

Starting off with this question, our main objective was to better understand how COVID-19 and the related lockdown measures reveal and sometimes exacerbate existing inequalities but also provide space for new inspiring initiatives and practices to emerge. Hence, we conducted from March to November 2020 a series of phone interviews and surveys with different groups of farmers and farm laborers in Maharashtra (India), in the agricultural plains of the Gharb and the Saiss regions and in the Draa Valley (Morocco), and in the M'zab valley (Algeria). In this paper, we present and analyze the findings of our remotely conducted fieldwork.

Notably, the socionatures and histories of Morocco, Algeria and India, and of the specific regions in which we work, are very different. However, a common thread between these countries relates to the importance of small-scale agriculture for the national economy and in supporting the livelihoods of a big slice of the population. In India, small-scale holdings $(<2.0$ hectares) comprise $86 \%$ of total land holdings [Government of India (GoI), 2019]. In Algeria as well, 70\% of farmers are small-scale farmers, according to the agricultural census of 2001 [Food and Agriculture Organization (FAO), 2020]. A similar situation exists in Morocco, where small farms make up 70\% of total landholdings (Verner et al., 2018). In addition, in the three countries, agricultural wage work is extremely important for the livelihood of the rural population [The World Bank, 2019; Food and Agriculture Organization (FAO), 2020; Kumar et al., 2020]. Although often working in poor conditions and without contracts or access to social security, agricultural laborers contribute greatly to make the agricultural sector of each

\footnotetext{
${ }^{1}$ With small-scale farmers and agricultural laborers, hereafter also referred to as agricultural actors, we mean people involved in small-scale agriculture: some of them farm only on their own -or their household's-land (no more than 2.0 hectares); some also work on other people's farm to complement their income; some do not own land and work exclusively for others.
}

respective country flourish (Bossenbroek, 2016, 2019; ThérouxSéguin, 2016).

Moreover, similar processes of agrarian change have characterized these three countries in the past decades. Neoliberal-driven reforms have encouraged farmers, including small-scale farmers, to start cultivating more and more commercial crops for national and international markets (see among others Akesbi, 2011; Joy et al., 2014). Changes in cropping patterns have gone hand in hand, among other dynamics, with (ground)water overexploitation (e.g., Llamas and Martínez-Santos, 2005; Shah, 2005; Kulkarni and Shankar, 2014; Bossenbroek et al., 2015), increased land tenure insecurity, higher agricultural costs and thus indebtedness and exposure to market volatility (e.g., Mohanty, 2005; Joy et al., 2014). Drought, water salinity and irregular precipitation patterns also posed significant challenges for farmers (e.g., Kuchimanchi et al., 2019). On top of this, COVID-19 and the related lockdown measures disrupted the global food production and distribution system, exacerbating existing inequalities at different scales (Clapp and Moseley, 2020; van der Ploeg, 2020). As such, the pandemic more forcefully brought to light the dimensions of an ongoing crisis that small-scale farmers are already experiencing in terms of ever greater uncertainties and unpredictabilities. Yet how these crises and processes of change become manifest in individual lives and livelihoods shaped by prevailing axes of social differentiation alon along the lines of gender, class, and age (O'Hara, 1998; Ramamurthy, 2003; Bossenbroek et al., 2015; Bossenbroek, 2016; Domínguez Guzmán et al., 2017; Domínguez Guzmán, 2019).

In this paper, we propose a modest and situated analysis of the implications of the COVID-19 pandemic on the lives of different actors involved in small-scale agriculture, drawing on their personal experiences and narratives. However, rather than drawing comparisons between the different cases, or using our empirical material to identify larger generic patterns, our aim is to engage in a joint reflection and conversation about our observations, findings and interpretations. In presenting and analyzing our data, we try to remain as faithful as possible to the complexity of the documented experiences, relations and practices of the different agricultural actors we talked to, by carefully and humbly listening to their many different voices (O'Hara, 1998; Ramamurthy, 2003, 2010; Bossenbroek et al., 2016; Domínguez Guzmán et al., 2017). Doing this shifts the attention away from how COVID-19 has emphasized the violent features of the modern industrial agriculture and food system (Béné, 2020; Clapp and Moseley, 2020; Timilsina et al., 2020; van der Ploeg, 2020), to instead shed light on the very material implications of COVID-19 on the everyday lives and livelihoods of people involved in small-scale agriculture and their inventive practices to address them as good as they can.

In paying attention to the complexities and specificities of everyday experiences, we are inspired by feminist ethnographies that let small facts speak to large issues, or large concerns (Gibson-Graham, 2014). For us this means conducting a careful empirical work, drawing on the everyday to appreciate the multiplicity of different people's lived experiences, relations, and practices. It also means that we do not analyze the mundane, the empirical, as an incidence of a larger structure or discourse, but 
as a moment that is "sensitizing but also unique" (Mol and Law, 2002: 16). After all, as critical ethnographers-we do not aim to "fabricate bounded, coherent, and essentializing 'cosmologies" (Bonelli, 2016), nor does our form of theorizing consist of either confirming or refuting larger structures or patterns of change. Rather, we use theory to think with, letting our rich but also partial and incomplete empirical material to converse with theory (see also Domínguez Guzmán, 2019).

The paper is structured as follows. In the next section we introduce the theoretical concepts we use to read through the ethnographic material and weave together connections across sites. Thereafter, we discuss more in detail the contexts of our research and the methods we used in the different countries to collect data, including reflections on the challenges of conducting fieldwork remotely. Our analysis is then presented along two main research lines. Firstly, employing an intersectional lens, we focus on how different small-scale farmers and agricultural laborers experience COVID-19 and the lockdown in various material ways. Thereafter, our second line of analysis focuses on individual and collective responses of different agricultural actors to respond to the challenges faced during the COVID-19 lockdown. In the final section, in light of our analysis and process of joint learning, we will draw some conclusions.

\section{INTERSECTIONALITY, RESILIENCE, AND CARE: CONCEPTS TO THINK WITH}

The three main theoretical concepts we interweave and use in this paper to think with our empirical data are intersectionality, resilience, and care. We decided to engage with them as they kept emerging in our conversations since we started our research project. We acknowledge that these concepts are at the center of important theoretical debates. For this reason, we here briefly unfold how we approach and mobilize them empirically as they are useful for understanding our data.

Firstly, intersectionality, as a concept developed in feminist literature, allows us to think how inequalities-and the different types and degrees of exclusion and oppression that they entail-are often shaped by different and intersecting systems of domination (e.g., Crenshaw, 1989; Yuval-Davis, 2006; bell hooks, 2014). In this regard, feminist political ecologists, have shown how, especially in agrarian contexts, access, and use of natural resources-and thus also roles, responsibilities, labor relations and decision-making processes-are very much shaped by intersecting axes of social differentiation such as gender, class, caste, age, ethnicity (see among others, Crow and Sultana, 2002; Gururani, 2002; Harris, 2006; Nightingale, 2006, 2011; Elmhirst and Resurreccion, 2008; Sultana, 2011). Though we do not have all data needed to conduct an in-depth intersectional analysis of the implications of COVID-19 in the contexts where we work, throughout our discussion we remain sensitive to how experiences and responses differ among different respondents. Importantly, in the three countries where we conducted research, deeply patriarchal social structures permeate various levels of governing land (and other) resources, and contribute to the reproduction of a public imagination of the farmer as an individual adult or elder male landowner. In India, patriarchal discourses importantly interweave with the caste system to constitute institutional and social dynamics in which (single) women farmers and agricultural laborers from scheduled castes are often the most marginalized and discriminated (Agarwal, 1992, 2003; Chakravarti, 1998; Chen, 1998; Kulkarni and Bhat, 2010; Padhi, 2012; Krishna and Kulkarni, 2018). In the Moroccan and Algerian contexts as well, different studies have illustrated how patriarchal family and kinship hierarchies and existing gendered social-cultural norms hamper rural young women to pursue their farming aspirations and their possibility to access resources (Salhi, 2010; Bossenbroek et al., 2015; Ftouhi et al., 2015; Lahmadi et al., 2016). Certainly, we recognize that gender relations, roles, and responsibilities unfold differently in the three countries, also intersecting with age, class, ethnicity factors. At the same time, while being cautious of generalizations, we trace some common and interesting threads weaving the experiences of some groups of agricultural actors in the three countries. ${ }^{2}$

Secondly, the notion of resilience has been used across different epistemic communities and fields, ranging from mathematics, physics, and engineers to ecology and social sciences, development studies, and urban planning (for reviews of studies on resilience see Cote and Nightingale, 2012; MacKinnon and Derickson, 2012; Simon and Randalls, 2016). It has been mobilized by scholars and policy-makers, practitioners, and activists, in multiple, malleable, and often very abstract ways, generally referring to the capacity of a system, or a group of people to respond, adapt, or deal with crises, change, and uncertainty (Walker and Cooper, 2011; MacKinnon and Derickson, 2012; Simon and Randalls, 2016). The term resilience has often been used as a "boundary object," "floating between descriptive and normative meanings" (Brand and Jax, 2007). One of the most well-known and discussed approaches to resilience thinking originates in natural sciences and ecology but integrates social components to study the capacity of socio-ecological systems (SES) to continue functioning in spite of change. This approach inspired social scientists to conceptualize social resilience as the capacity, or strategies, of people living in different environments to cope with external (social, political, and/or environmental) disturbances (Adger, 2000). Yet many theoretical approaches to resilience, and particular the socio-ecological systems framework, have been criticized by political ecologists as they fail to account for the violence and power hierarchies structuring the systems, or the orders that are disrupted or threatened (Ingalls and Stedman, 2016); and for ignoring the plurality of epistemologies and ontologies that co-exist and co-produce the world (Bell, 2005; Walker et al., 2006; Cote and Nightingale, 2012; Tozzi, 2021). In other words, too often resilience has been mobilized as a tool serving (neoliberal) governance programmes, where

\footnotetext{
${ }^{2}$ Recent (feminist) scholarly work on the implications of COVID-19 particularly in urban contexts further pointed out the usefulness of adopting an intersectional approach. Some groups have been affected by this global pandemic much more than others: minorities (especially ethnic minorities), socio-economically disadvantaged people, the elderly and women (Agarwal, 2020; Ali et al., 2020; Bahn et al., 2020; Butler, 2020; Hay, 2020; Kulkarni, 2020).
} 
authorities are de-responsibilized and individuals-especially those most marginalized-are urged to cope, adapt, and sustain themselves in the face of multiple stresses and contingencies (Welsh, 2014). In this regard, MacKinnon and Derickson (2012: 263) have proposed the notion of resourcefulness as an alternative to resilience in order "to problematize both the uneven distribution of material resources and the associated inability of disadvantaged groups and communities to access the levers of social change." Other scholars have preferred to stick to the term resilience, but they similarly emphasized the importance of approaching it in a context-specific manner that seeks to consider, among other elements, the very material challenges that different individuals and groups face (e.g., limited, uncertain, or difficult access to resources) as politically charged issues of maldistribution and misrecognition (see among others Cote and Nightingale, 2012; Locke et al., 2014; Jordan, 2019). In other words, sociocultural factors and relations of poweroften embedded in institutions-significantly shape the response options available to different actors to make decisions and act in relation to change (Cote and Nightingale, 2012; Tozzi, 2021). Hence, the importance of unfolding and embracing the specific ways of knowing and being of different individuals and groups, as they shape-situated-priorities and ways to respond to crises (Cote and Nightingale, 2012; MacKinnon and Derickson, 2012; Tozzi, 2021). This way resilience can become more than a process to maintain - or return to-particular socionatural configurations; it can open up ways to transform those configurations in attempts to circumvent the disturbances that caused the struggles in the first place.

Thinking with resilience from this critical and grounded perspective allows us, first of all, to identify and document the material challenges that different people involved in smallscale agriculture are facing in the context of COVID-19 and the socionatural and political dimension of those challenges, which go much beyond the current pandemic. Secondly, it inspires us to reflect on how different agricultural actors persist, adapt, and transform (see also Keck and Sakdapolrak, 2013), individually and collectively, in light of these challenges through everyday practices informed by a cumulative process of learning, sometimes mediated by other actors, including the government, civil society, researchers-activists, and other organizations.

The last concept we will use to think with throughout our empirical analysis is the concept of care. Care has been used in many different ways by feminist scholars, especially in feminist political economy and feminist political ecology scholarships. In the context of our research we approach care in two entangled ways. On the one hand, we look at care work in relation to the fundamental practices that ensure social reproduction (especially domestic work and taking care of children), which are often invisibilized and fall beyond the paid economy. This is because COVID-19 and the related lockdown have underscored the enormous importance of care work, both in the private and in the public domains, and how this is overwhelmingly performed by women (Bahn et al., 2020; Craig, 2020; Power, 2020). At the same time, we reflect with care in a broader sense. Following the feminist scholars Fisher and Tronto (1990: 40), we embrace a definition of care as "everything that we do to maintain, continue, and repair 'our world' so that we can live in it as well as possible. That world includes our bodies, ourselves, and our environment, all that we seek to interweave in a complex, life sustaining web." Drawing on this definition, Puig de la Bellacasa (2012) emphasizes the relational character of care: we care because we are interdependent. In this regard, practices of care can encompass both professional and everyday types of care, being the "persistent tinkering in a world full of complex ambivalence and shifting tensions" (Mol et al., 2010: 14). In this broader sense, care blurs the divide between rational, technical, and emotional (Mol et al., 2010; Puig de la Bellacasa, 2017) but also between the private and the public, the personal, and the political (Escobar and Harcourt, 2005; Mol et al., 2010; Tronto, 2013). Practices of care can be driven both (and often simultaneously) by deliberate affection and love, and by a sense of obligation and constraint (Puig de la Bellacasa, 2012), involving both the human and the more-than-human world (Puig de la Bellacasa, 2012, 2017). In our research, we shed light on how different actors involved in small-scale agriculture engage in, perform and re-think practices of care in times of COVID-19, to support their own and their loved ones' well-being. Unfolding how these practices are or are not mediated by other actors (e.g., government, civil society) and how they may involve the more-than-human world provide interesting insights in how people relate and collectively cope with change, potentially in transformative ways.

\section{METHODOLOGY AND RESEARCH CONTEXTS}

How do ethnographers and activists work "from home" during a global pandemic? When the lockdown started in March 2020 we did not have a straightforward answer to this question. Perhaps no one did. Resources and literature on digital ethnography and on conducting surveys and interviews remotely started to abundantly circulate through university and research networks mailing lists (see among others the repository compiled by Lupton, 2020). Though research has been conducted remotely by phone or through digital platforms for many years-mostly focusing on western societies-COVID-19 caught everyone unprepared, especially researchers/activists working in rural areas or in low and middle-income countries. In most casesincluding ours-conducting remote fieldwork became the only option to continue doing ethnography.

We wanted to remain engaged with the farmers and agricultural laborers with whom we had been working before the lockdown in different areas of Algeria, Morocco, and India (Figure 1). We did not want to disappear safely in our home offices during such worrisome circumstances. We thought that perhaps it was exactly in these times that research and activist engagements become even more important: when new challenges emerge, worlds are shaken, dynamics of exclusion, and oppression may (further) materialize, but also where potentially unexpected changes for the better may begin and promising alliances might be formed.

In all three countries, our research idea was motivated by the importance of carefully listening to the voices of farmers and 


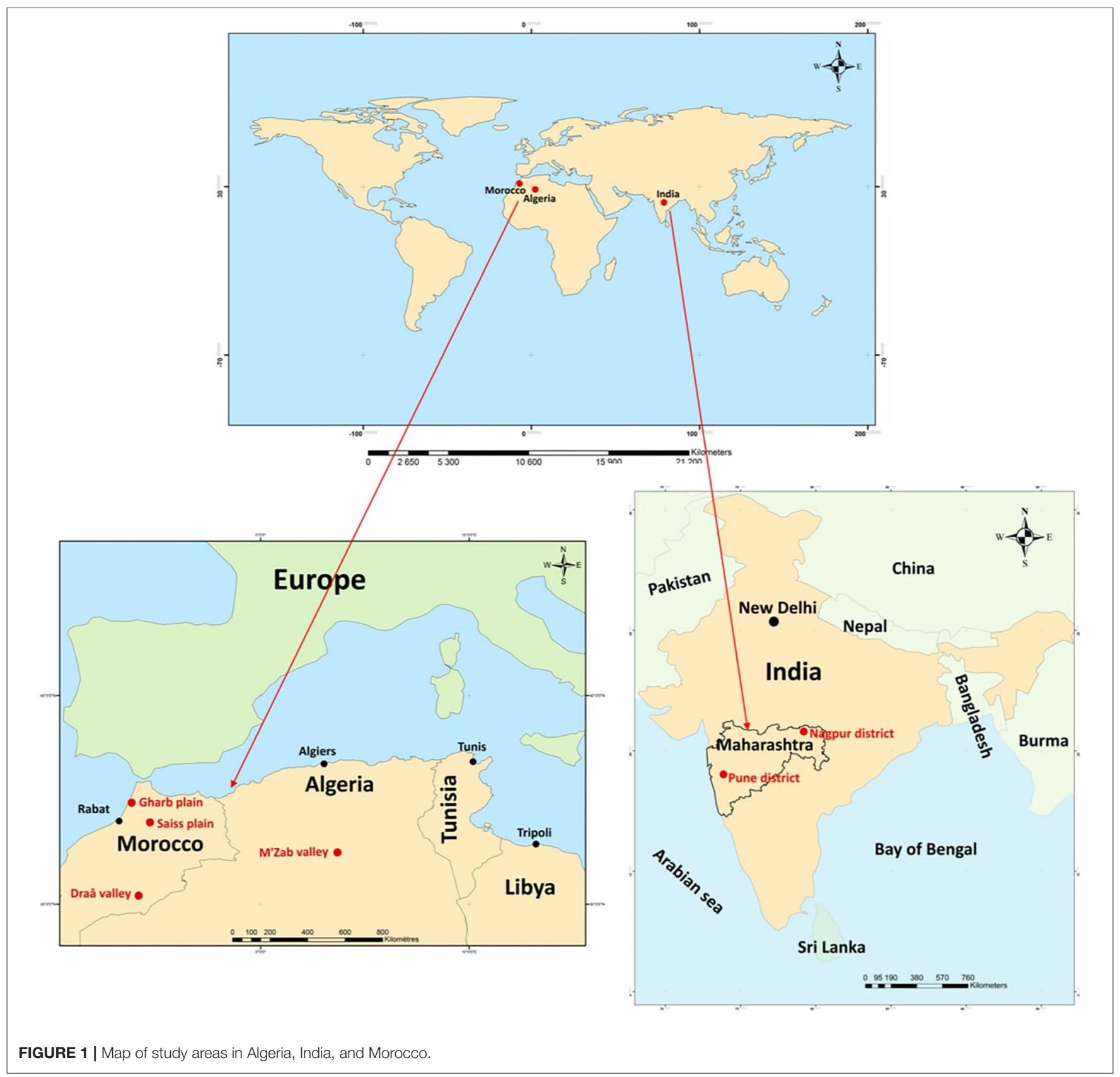

agricultural laborers who already dealt with so many entangled challenges and uncertainties and who belong to the poorest sections of the rural population. Not only to trace and shed light on their possible further marginalization in the context of a global pandemic, but also to identify and give space to their strength, their ways of rethinking how to survive and take care of their current and future well-being. We collected data mostly through phone interviews with farmers and agricultural laborers between March and November 2020. Text messages and photos exchanged through mobile phones apps have also been part of the data collection process. However, each country team also developed their own specific methods and involved different respondents (see Table 1 for more details), based on existing contacts and focus of different ongoing research projects.

Conducting fieldwork remotely is challenging and very different from the face-to-face ethnographic experience we are used to. We may imagine where different respondents are while talking to us on the phone and who is around them, but we do not really know. The richness of an embodied ethnographic encounter is lost. The lack of information on non-verbal communication, places (e.g., homes, farms, squares), smells, sounds, circumstances, force us to conduct our data analysis and write our ethnographic narrative remaining almost exclusively at the level of the spoken conversation, of the text 
TABLE 1 | Methods used in the different study countries.

\begin{tabular}{|c|c|c|}
\hline Country & Location & Methods \\
\hline India & Maharashtra state & $\begin{array}{l}40 \text { telephonic interviews conducted between April and November } 2020 \text { with women farmers, and agricultural laborers } \\
\text { from seven districts of Maharashtra, and particularly Pune and Nagpur districts. } \\
\text { Telephone survey of } 946 \text { single women farmers and agricultural laborers across } 17 \text { districts of Maharashtra, conducted } \\
\text { through the MAKAAM network. }\end{array}$ \\
\hline Morocco & $\begin{array}{l}\text { Draa Valley, the Saiss } \\
\text { Plain, and the Gharb } \\
\text { Plain }\end{array}$ & $\begin{array}{l}70 \text { semi-structured telephone interviews conducted with farmers ( } 5 \text { of which were women) and agricultural laborers (all } \\
\text { men) conducted between April and November in the Draa Valley. } \\
15 \text { semi-structured telephone interviews with female agricultural laborers and farmers (men and women) in the Saiss } \\
\text { Plain and the Gharb Plain and } 12 \text { structured questionnaires with female agricultural laborers. } \\
\text { Interviews were supplemented by photo and video exchanges and voice messages shared through WhatsApp. }\end{array}$ \\
\hline Algeria & M'zab valley & $\begin{array}{l}77 \text { telephone interviews with men farmers and breeders, agricultural laborers mostly from Sub-Saharan countries, } \\
\text { sellers of agricultural inputs and civil society; follow-up of the interviews through WhatsApp and Facebook. }\end{array}$ \\
\hline
\end{tabular}

(Holt, 2010). Only in a few cases we were able to conduct video phone calls and receive pictures through mobile phone apps accompanying the narratives of our interviewees.

As mentioned before, the cases we study are differentiated by their socionatural character and historic formation. In India the study was conducted in the state of Maharashtra: this is the most industrialized Indian state, though about half of its population lives in rural areas and agriculture is still the main occupation (Yadu and Satheesha, 2016). In the past 40 years, Maharashtra has faced several dimensions of an agrarian crisis related to processes of agrarian change involving water re-allocation from subsistence farming to commercial farming, exploitative employment of agricultural laborers in agribusinesses, increased indebtedness of small-scale farmers, farmers' suicides (Mohanty, 2005; Sahay, 2010; Joy et al., 2014). Our research focused mostly on women farmers and agricultural laborers, and particularly single women (unmarried, deserted, widows). In fact, though about half of the people involved in small-scale agriculture in Maharashtra are women, they are often socially and institutionally not recognized as "farmers," something documented also in other parts of India (Agarwal, 2003; Kulkarni and Bhat, 2010; Padhi, 2012). The data collection was conducted in close collaboration with MAKAAM (Mahila Kisan Adhikar Manch), a nationwide network of activists, women farmer collectives and organizations working to secure due recognition and rights of women farmers.

In Morocco our fieldwork covered three regions: the Draa Valley, the Saiss, and the Gharb Plain. The Draa Valley, in the south-east of the country, is known for subsistence farming. However, in recent years, new agricultural investors have entered the region and an increasing number of local farmers, mostly young local farmers, started cultivating commercial crops, and particularly watermelons, both aimed for the national and international markets. Changes in the agricultural landscape of the Draa Valley have created new opportunities for young farmers but have also gone hand in hand with new dynamics of socionatural exploitation. Water is becoming scarcer due to droughts and over-exploitation (Karmaoui et al., 2016; Bossenbroek, 2019; Berger et al., 2021)—putting at risk the livelihoods of small-scale farmers who cannot compete with larger, wealthier farmers. In the Saiss and the Gharb Plains, in the North of Morocco, our investigations focused mainly on the experiences of women agricultural laborers. These regions constitute two of the main agricultural basins in Morocco. Whereas, the Gharb is famous for the production of different kinds of berries, mainly for export, the Saiss is known for the production of vegetables and recently also for different kinds of fruits. Most are sold locally; a smaller quantity is exported. Importantly, these regions attract each year a large mass of men and women who rely on agricultural wage work to support their and their families' livelihood throughout the year.

In Algeria, our work focused on the M'Zab Valley, located in the Algerian Sahara, about $600 \mathrm{~km}$ from the capital Algiers. Like most oases, the M'Zab Valley is characterized by the coexistence of two agricultural landscapes: the ancient palm groves created in the eleventh century, where traditional palm trees are cultivated, and the new agricultural extensions created in the 1980s, located at the periphery of the old palm groves (Bisson, 2003; Hamamouche et al., 2018). These extensions are characterized by diversified farming systems mainly oriented toward the intensified cultivation of commercial palm trees and horticultural crops (Cote, 2002). The M'Zab Valley faces several processes of degradation mainly due to rapid urbanization and degradation of natural resources-in particular the depletion and pollution of aquifers-which raises concerns about the sustainability of palm groves cultivation, but also of the existing oases (Bouchair, 2004). In this area, we conducted interviews with different local actors: local farmers and breeders, sellers of agricultural inputs and people working in the civil society. Though women and men work together in the farms-performing different tasks-we unfortunately were able to get in touch only with men. Differently from Morocco and India, in Algeria we had no direct contact with women farmers before starting this research and because of the patriarchal norms characterizing the Mozabite community, we were not able to get in touch with women farmers remotely. For this reason, in our analysis, we will be extra cautious in interpreting second-hand data on women farmers and agricultural laborers in Algeria. We also interviewed men agricultural laborers, both Algerians and migrants coming from sub-Saharan countries. The latter are usually undocumented and work temporarily in Algeria, as they try to save money to reach Europe. 


\section{SMALL-SCALE AGRICULTURAL ACTORS AND THE MATERIAL IMPLICATIONS OF COVID-19}

In what follows we illustrate some of the material consequences of the COVID-19 crisis on different actors involved in small-scale agriculture and how these interweave with existing socionatural challenges and uncertainties. In doing so, we also zoom in on the experiences of women farmers and agricultural laborers, particularly widows and single women in India and in Morocco who have been notably impacted by the pandemic and by the constraints imposed by the lockdown. We unfold how the lockdown measures affected farming and labor practices as access to the market was limited and mobility and work opportunities constrained. Moreover, we reflect on women farmers and agricultural laborer's increase in unpaid care work and on their limited access to government support schemes.

\section{Difficulties to Commercialize Crops}

As soon as the lockdown started, at the end of March 2020, small-scale farmers started facing difficulties to sell their produce. Often, in order to sell at least part of their harvest, they had to accept very low prices. In the Draa valley, in Morocco, the young local watermelon farmers (under 35 years old) harvested their produce in April (2020), just weeks after the lockdown started. As watermelons in this region are foremost produced for the national and international markets, farmers are strongly dependent on national intermediaries and buyers traveling to the region during the harvest period. These middlemen negotiate the price of watermelons with farmers in relation to supply availability and market demand. Due to transport and mobility constraints, and to the excessive administrative proceedings required to travel from one region to the other, only a few buyers and intermediaries were able to reach the watermelon farms. At the same time, farmers could not reach nearby cities and smaller towns by themselves and the souks (weekly local markets) remained closed due to the lockdown for several months. Consequently, these young watermelon farmers, who combine small-scale commercial farming with subsistence farming, faced difficulties in selling their produce at profitable prices. Ahmed, ${ }^{3}$ one of them, indicates: "There are only a few buyers and they install a monopoly on watermelons. They decide on the price, there are no other alternatives. Before when there were more buyers we were able to negotiate prices." With watermelons only staying well for a few days, the young farmers were forced to accept low prices. Yet they had to leave part of the harvest on the field to rot.

Similarly, throughout Maharashtra, in India, when the lockdown started, most farmer markets closed, public transport was stopped and paying for private forms of transport, such as (shared) rickshaws, became unaffordable for most of the smallscale farmers we interviewed. For this reason, they had to leave much of the harvest on the field to rot. Meena, a woman farmer from the Pune district explained: "We [she and her husband] had grown fenugreek but much of it got wasted because no vendors came to pick it up, and it was not possible for us to transport it

\footnotetext{
${ }^{3}$ Pseudonyms used for all names to protect the identity of the respondents.
}

and sell it elsewhere. Everyone from the village grows their own vegetables, so there is no market here." Not only farmers, but also cattle breeders faced difficulties during the lockdown as the demand for milk significantly decreased due to the closure of markets and restaurants.

In the M'Zab Valley, in Algeria, the prices of dates, a crop that can be stored for a very long time, dropped significantly during the second wave of COVID-19 infections, in October 2020. Farmers faced difficulties particularly in selling dates of the Deglet Nour variety, which is mainly produced in the new agricultural extensions for commercial purposes. To escape the monopoly of intermediaries who have a strong grip on the marketing price, small-scale farmers usually store this variety of dates in cooling stations. This way, they can sell them for better prices throughout the year, exporting them to Sub-Saharan countries and to Europe but also selling them on the national market at specific festivities (e.g., during Ramadan, at weddings and funerals). However, this year in October, when the new dates were ready to be harvested, the cooling stations were still packed with last season's harvest because the border traffic remained limited since March 2020, markets were closed and festivities and family gatherings prohibited. Malik, one of the farmers we interviewed, told us: "We have spent a lot of money for pollination and for maintaining the commercial palm trees, especially the high-value varieties. We cannot stand a greater deficit year." As a consequence, many farmers had to sell large quantities of Deglet Nour dates from last year at low prices (about half the usual price) to large local food processing companies in order to save some storage capacity for this year's harvest. In the past years, only downgraded dates were destined for processing. Other farmers decided to harvest only the dates of common varieties that are mainly for self-consumption and to delay up to 2 months the harvest of commercial varieties. For instance, Kamel explained: "As long as I don't have better market visibility, I will delay the harvest of commercial dates." However, this decision generated additional costs, especially water related costs: to prevent the dates from withering, farmers had to continue irrigating the palm trees while waiting to find a profitable market. At the same time, the harvest of dates could not be delayed forever as these would start rotting on the tree. After 2 months, farmers preferred to sell the remaining dates at a very cheap price than not to sell them at all, also to make sure to have greater financial liquidity to invest in the next cropping season. Less resourceful farmers who cultivate commercial dates on very small plots in the old Mozabite palm groves got even more affected, as local middlemen did not want to buy their dates in the first place, considering the uncertainty of the market. They thus had to leave much of their produce to rot in the palm groves and did not make any profit.

Our data from India shows how negotiations to market crops can be marked by gender inequalities. Small-scale women farmers in Maharashtra in general face particular difficulties to get reasonable prices for their produce. This is because women rarely own land, as they continue to be disinherited (Bhat, 2016; see also Agarwal, 2003; Kulkarni and Bhat, 2010). Hence, single women and widows often cultivate land officially owned by someone else-mostly male members of their extended familywhich also limits their access to bank loans for agricultural 
inputs and government support schemes. They therefore need to rely on private money lenders, having to accept very high interests. Moreover, women farmers usually have limited access to procurement centers where specific crops can be sold at government-established minimum support prices. This is also due to the fact that single women lack the required documentation to access these centers, especially those related to land titles. Besides, government procurement centers are located far from villages, and most often managed exclusively by men. Even when they do have land titles, women farmers find it very difficult to transport their produce to these centers as well as to negotiate prices. At the same time, they do not have space to store their produce at home or in the farm for a long time. For these reasons, single women farmers often do not have other options but to sell their harvest to local traders, having to settle for prices lower than the minimum support price, and thus earning comparatively less for the same effort. These dynamics of exclusion and marginalization worsened with the implementation of the lockdown measures. Reaching government procurement centers became even more difficult for women farmers; negotiating prices almost impossible. For this reason, single women and widows found themselves even more dependent on private traders and money lenders and on the male members of their extended family. The testimony of Vasanti, a widow farmer illustrates this issue: "I had to sell my cotton to the same trader who gave me seeds and inputs on credit. Otherwise he would not extend the credit next year. I do not go to the procurement centers. Only men go to the procurement center." This way she could at least get some return from her investment and not have to fully waste a good harvest. However, this shows how gender and marital status intersect and shape the impacts of the crisis on different groups in society. The experience of Neeta, a widow farmer who does not own any land but cultivates her father-in-law's, is also relevant in this regard. She lives in her natal village because in her marital village "there is no place for her." Usually she travels every day to her farm but once the lockdown was implemented, she could no longer do so. For this reason, her only option was to ask people in her marital village to harvest the produce in her farm, something that increased her dependency and indebtedness to her marital family. The circumstances created by the COVID19 pandemic reinforced patriarchal power relations, contributing particularly to the (increased) indebtedness of women farmers and significantly hampering their capacity to make ends meet and thus also to invest in the next cropping season.

\section{Labor Shortages and Lack of Labor Opportunities}

The organization of agricultural labor has also been strongly impacted during the lockdown. This has first of all negatively affected small-scale farming families who depend on agricultural laborers and even more agricultural laborers themselves. Those households that cultivate their own land and usually hire laborers to perform some farming tasks such as weeding and harvesting, preferred to manage all the work among family members. In this way they attempted to minimize contact with other people and thus the risk of being infected as well as to limit the expenses for agricultural inputs-given the difficulties in commercializing the produce.

At the same time, agricultural laborers who are used to traveling to work on farms could not easily do so, as mobility was blocked, public transport not available and gatherings at pick-up places were not allowed. In the three-study areas in Morocco, we were told that the moquefs-places usually situated at the outskirts of small cities, where agricultural laborers gather in order to find a job for the day-were banned. This made it very difficult for laborers-and especially for women laborers-to find work. Men laborers had more options to organize work in alternative ways, despite the restrictions (as we will better outline in section Reinventing Farming Practices in Times of COVID-19). In some cases, they were even able to increase their profits, asking for higher wages, as farmers were in extreme need of laborers. In the Draa Valley for instance, the harvest of watermelons relies on a regional workforce with laborers (foremost men) coming from nearby towns and cities. The relatively high demand for labor compared to the availability of agricultural laborers, led to higher wages, as it became increasingly difficult for laborers to travel to and across rural areas. For example, the price of loading a truck of watermelons increased significantly. Usually, it ranges between 1,400 and 1,500 Dirham ( \pm 130 to \pm 140 euros), depending on the truck size, while this year, the price reached $2,000-2,500$ Dirham ( \pm 185 to \pm 230 euros).

The situation was similar in Algeria where the travel restrictions imposed between different Algerian regions impacted on the availability of skilled agricultural laborers. Usually, the date harvest in the M'Zab Valley, and particularly the harvest of the Deglet Nour dates, relies on laborers coming from the Timimoun region, about $600 \mathrm{~km}$ away. In fact, laborers specialized in harvesting dates are part of a socio-ethnic group descending from the slaves that used to work in the M'Zab Valley. These used to be called "khammès" (which means sharecropper to the fifth) as they farmed the land in exchange of one fifth of the harvest. The descendants of the khammès gradually returned to their native region (Timimoun) after the land reform of 1971, implemented to distribute land to landless peasants and changing the social status of the descendants of the khammès (Aït-Amara, 1999). However, this year in October, these skilled laborers could not travel to the M'Zab Valley because of mobility constraints. Hence, they have been affected disproportionately, as they could not work. At the same time, this meant that the salary of the few laborers available in situ increased by about one third: from 400 to 600 dinar per palm tree ( \pm 2.5 to \pm 3.75 euros). Sub-Saharan migrants (all men) living temporarily in the area-and who are often exploited and marginalized because of their ethnicity and because they are undocumented-benefitted from this situation as they could work as agricultural laborers in the palm groves and earn more than usual. They told us how land owners would treat them particularly well to make sure they would not try to leave to go work elsewhere.

The lockdown constraints, especially during the first month, had drastic implications for agricultural laborers in Maharashtra and in Morocco's Gharb and Saiss Plains, where most agricultural 
laborers are women. Many of them rely on farm wage labor for their primary earnings, as they tend to be precarious backgrounds, often not owning any land, or only cultivating very small plots. For single, deserted women and widows particularly, wages earned as laborers are essential to provide for themselves and often for entire families. In Maharashtra, about half of the women agricultural laborers we talked to did not get a single day of paid work during the lockdown months from March to June, mostly due to mobility constraints [see also Mahila Kisan Adhikar Manch (MAKAAM), 2020]. Janaki, one of the single women we interviewed, explained: "Our village is mostly unirrigated, and we do not have agricultural work during summer. Usually we get some work in nearby villages, for things like irrigating or picking turmeric or chilies. The farmer sends a rickshaw for us. But during the lockdown that was not possible." The fact that migrant workers-mostly men-who lost their jobs in cities returned back to villages, also decreased the work availability for women (see also Agarwal, 2020).

Similar experiences were encountered in Morocco (Bossenbroek and Ftouhi, 2021). The lockdown was implemented early spring, when the demand for labor is usually at its peak. During regular years, women laborers go to the moquefs and are able to negotiate their daily wages, and usually get decent salaries: up to 180 Dirham (about 17 euros) per day. Yet, this year, the women laborers we interviewed complained that they faced huge difficulties in finding work as the moquefs were banned. In the Saiss region, some women laborers told us that they were ready to be paid very little as any income would be better than no income at all. One of them told us: "Those who are going to the moquef are ready to work for 50 Dirham a day [about 5 euros] just to be able to pay their rent, and to provide food for their children. They do not have any choice." Because of reduced incomes they were forced to limit their expenses. Khadija, a widowed agricultural laborer explained: "I could not afford to provide my child with the means to take online courses... I do not have a smartphone... he could not take the courses on TV either because ours is damaged and I do not have the money to buy a new one." Souad, another laborer in Morocco married to a much older man and with three children, told us that she had to ask her daughter to quit her studies at the University of Meknes because she could no longer afford to support her. Others were not able to afford proper meals, and had to adapt their diets accordingly.

\section{Difficulties to Access Government Support Schemes}

In Morocco and in India, the national government launched several initiatives to support socio-economically marginalized groups. In Morocco, the "Tadamon" (solidarity in Arabic) program was meant to provide financial support to the poorest sections of the population during the COVID-19 pandemic. However, the rural population, and particularly single women farmers and agricultural laborers, often did not benefit from them. In fact, even in cases where the woman is the main provider for her family, the husband or father (in-law) is considered the de facto head of the household, hampering women to directly apply for government support schemes. In other cases, women would say that they had difficulties filling in the requested forms or they were refused support because of not following the procedure correctly. They would attribute this to the fact that they are illiterate. As Fdila, aged 45 and wage worker in the Saiss, mentioned "an illiterate person is like a person who walks in the darkness." All three requests that she put in to get government support were rejected.

Throughout Maharashtra, India, the institutional marginalization of single women farmers emerged even more evidently from our data. At the end of March 2020, the central government announced a COVID-19 emergency aid package as part of the "Pradhanmantri Garib Kalyan Yojana (PMGKY)" (Prime Minister poor welfare scheme) to provide relief to the most socio-economically disadvantaged groups. This entailed, among other measures, the distribution of free rations of food grain through the existing public distribution system, and cash transfers through existing government support plans such as the widow pension scheme and a scheme that provides financial aid to the poorest farmers. The vast majority of the women who we talked to had access to the free rations during the lockdown months [Mahila Kisan Adhikar Manch (MAKAAM), 2020]. However, these consisted only of rice. Because of the difficulties of generating income, many did not have cash to buy other essential items such as oil, vegetables and pulses. At the same time, many (more than half of our respondents) did not benefit from the cash transfers announced under the PMGKY as they were never registered for the above-mentioned schemes in the first place. Even when they had cash on their bank account, many women could not reach the banks in nearby towns due to mobility restrictions [Mahila Kisan Adhikar Manch (MAKAAM), 2020]. Significantly, almost none of the women we talked to had access to the "Mahatma Gandhi Employment Guarantee Act (MGNREGA)," a government scheme developed to enhance livelihood security in rural areas by providing wage employment to adults willing to do unskilled manual work. One of the reasons for this was lack of awareness among people regarding the act itself and its procedures. Less than half of the women we interviewed had the necessary documentation (job cards) to apply for these government-subsidized jobs and almost all of them were anyway not familiar with the procedures to apply [Mahila Kisan Adhikar Manch (MAKAAM), 2020].

\section{Increase in Care Work}

Although there were several governmental and private initiatives to support the most affected ones during this time of crisis in all three countries, we learned that people in our research areas mainly relied on familial and community relations for support and care. Providing such support often adds to the already increased responsibilities of women, something that frequently emerged in the narratives of the women we interviewed in Morocco and India. As schools and kindergartens were closed, mothers, and particularly single mothers, had to juggle between working on the farm, taking care of most domestic tasks and looking after their children-something that increased their unpaid work burden and stress level, and further constrained their capacity to find work outside the household to make ends 
meet. Even in the case of married couples, our data suggests that the lockdown measures did not trigger changes in gendered labor relations within and outside the household or in the distribution of work, even if men were temporarily not working as wage workers and some migrated back from cities to rural villages. Women remained responsible for most domestic work while often also having to find new ways to support their and their family members' livelihood as income was affected by the lockdown (see also Agarwal, 2020; Kulkarni, 2020). In fact, many of the women working as agricultural laborers we interviewed in India and in Morocco, mentioned the necessity to continue their paid work on the farms in order to provide for their family, especially for their children, elderly or sick parents. In this respect, in the Saiss region, in Morocco, Souad, who is married to a much older man and has three children, told us how she was "in charge of providing for all the household needs." During the first month of the lockdown, some women had stopped working out of fear to get infected themselves, or to infect their family members. But once the little savings were exhausted, and loans were mounting, they were forced to find ways to continue working (as we will better illustrate in section Reinventing Farming Practices in Times of COVID-19).

These findings resonate with what has been pointed out by other feminist scholars who conducted research in COVID-19 times: the importance of care work, how most of it is performed by women, and much of it remains unpaid (see among others, Bahn et al., 2020; Craig, 2020; Power, 2020; Ticktin, 2020). Several of us, women and authors of this paper, also experienced an increase in care work during the lockdown months, having to suddenly juggle between working from home and homeschooling kids and/or caring for sick or anxious family members on top of many domestic tasks. The challenges some of us faced made us even more attentive to the struggles of the people who live in less fortunate circumstances with many more challenges caused by the pandemic and far greater uncertainties.

COVID-19 impacted the life of most, if not all, small-scale farmers and agricultural laborers struggling at the margins of profoundly unequal food systems, at local, national, and international scales. It also pointed out particularly how these margins remain highly patriarchal spaces, where women, particularly those socially neglected because of their matrimonial status (e.g., widowed, divorced, deserted) were often further marginalized and had to deal with (re)newed forms of exclusion and oppression.

\section{REINVENTING FARMING PRACTICES IN TIMES OF COVID-19}

The different material implications of COVID-19 and the related lockdown brought us to reflect on the response options available to different agricultural actors to continue to take care of their own and their household's well-being. In what follows we illustrate different forms of resilience emerging from our empirical work, focusing particularly on how resilience often emerges through different practices of care. Here as well we use an intersectional approach to tease out the different responses and possibilities of actors in dealing with the situation and embracing creativity, courage, and solidarity. Specifically, we narrate how some women agricultural laborers ignored the lockdown restrictions as they had to work secretly; how men agricultural laborers used virtual labor markets to find work; how farmers owning land changed their cropping patterns to cope with the situation; and how the pandemic inspired different collective initiatives toward more equitable and more sustainable socionatures.

\section{Re-arranging Labor Practices}

Many agricultural laborers could not afford to stop working during the lockdown. With little or no savings, often increasing debts to pay back, and limited or no access to government support schemes, they, and particularly landless (single) women, had to find ways to be able to continue working. Hence, they tried to circumvent the official COVID-19 restrictions and faced the risk of getting infected. In the Saiss Plain, in Morocco, agricultural laborers (mostly women) who desperately needed to work, tried to go to the moquef despite the ban. To avoid roadblocks and police checks they would go before sunrise as explained by Zineb, a divorced woman: "These days we work in secret so that the authorities do not see us." Farmers looking for laborers to harvest their ready-to-sell produce would pass by the moquef to stealthily pick them up. Other laborers, rather than going to the moquef, walked to nearby farms using secondary roads in order to avoid checkpoints. Zineb also indicated that during the lockdown, she started working as a paid caregiver in the house of one of her acquaintances who needed help with domestic chores. Yet again, she had to do this secretly, trying to avoid police checkpoints: "If they stop me in the street, I tell them I am just going shopping. Instead, I go to her [her acquaintance] house, I work and then I go home." In the narratives of women laborers particularly, the fear of being stopped and fined was added to the fear of getting infected. Forced to share transportation with other laborers to reach the farm, these women tried to minimize the risk of getting infected as much as they could. As Hafida, another divorced woman with a young son affirmed: "We disinfect our hands. I always take lavender soap and a little bit of bleach with me. I wipe my hands with my own towel and eat by myself, away from others during the break. Everyone eats in her own place on the plot. And when I get home, I take a shower and wash the clothes I was wearing outside."

With little resources available, resilience in these cases meant adapting working practices, despite the fear and the risks, in order to make a living. However, this did not necessarily mean accepting all conditions. Dignity and solidarity emerged even in the most desperate situations. In the Saiss Plain, in Morocco, for instance, Fatiha, a divorced woman with a young son and an agricultural laborer in extreme need of an income, would not accept a daily job from a farmer employer because she thought it was not paid enough. When he offered to pay more, she still refused as she felt it was not fair for other women laborers to be paid so little. She explained to us: "A farmer came to see me this morning, but he was not going to pay me well. He just wanted to give me 70 Dirham. I told him that it was not enough. So, he offered 80 but I shouldn't tell the other laborers. I told him no, that he must 
give us all the same remuneration." This quote also suggests that resilience is not simply engaging in individual practices to make a living, to adapt and survive in an extremely difficult situation: it can also be about supporting and caring for others that are in the same or in a similar situation. These women laborers have little resources to rely on, being very much marginalized institutionally and socially: yet they engage in everyday practices of care toward others, to fight for more just and equitable working conditions even in extremely difficult times.

More resourceful farmers came up with other, innovative and inspiring ways to organize labor in times of COVID-19. In the Draa Valley of Morocco, young watermelon farmers who usually rely on laborers coming from other nearby towns and cities, uses smartphones and social media to find laborers for harvesting. This way, Facebook and WhatsApp groups became a sort of virtual moquef. In case laborers did not have direct access to social media, they relied on information provided by their neighbors, or by friends who had a smartphone and could access the virtual moquef. As explained by Mohammed, a young laborer: "Farmers have WhatsApp or Facebook groups. You give your phone number to a farmer and ask him to share it in their group. When someone in the group needs laborers, they get in touch with you. Though then you need to find a way to reach their farms by yourself." In the case of these young watermelon farmers, technology played an important role in helping them to adapt to restrictive lockdown measures-opening up new ways to organize work, which could last beyond COVID-19. However, these alternative recruiting strategies only benefitted men laborers and those who are better well-off, who own a smartphone and can pay to access the internet. No women laborers mentioned to have used social media to find work, perhaps also because they felt safer to rely on their existing network of contacts, rather than on new ones based on social media. Also, the virtual labor market could be used exclusively by local laborers, and not by those ones who usually come from surrounding cities or other regions as these could not reach far-away farms.

\section{Changing Farming Practices}

In the case of small-scale farmers cultivating their own land, resilience emerged in other ways. Their concerns mostly related to which crops to cultivate in order to provide for themselves and their family members, while trying to minimize loss and debts. Our data shows changes in cropping patterns in all three study countries. These emerged as a way to deal with the challenges imposed by the lockdown and their entanglements with other pre-existing challenges and uncertainties. Vaishali, a woman farmer living in a drought-prone rural village in Maharashtra, India, told us: "We [me and my husband] are not going to plant flowers this year... maybe only some, on a small piece of land." Indeed, when the lockdown started in India, farmers were about to finish harvesting the rabi (winter season) crops, and to start planning for the next cropping season kharif (monsoon season). In Vaishali's village, in April, farmers usually sow mostly flowers, such as marigolds and chrysanthemums, which they sell at markets in nearby towns especially during important Hindu celebrations. Women farmers who perform most of the farming tasks, usually plant food crops for household consumption only on small portions of land or next to the flowers to take advantage of the drip irrigation system installed to irrigate this commercial and non-edible crop. In fact, in the past 15 years, in this droughtprone village, farmers have increasingly engaged in growing commercial crops for the national market. However, market volatility and irregular monsoon patterns make it very difficult for farmers to decide every year when exactly and which crops to cultivate. Chanda, a woman farmer living close to Vaishali explained: "You never know if it is going to rain enough, or too much. You never know how much you are going to be paid as market prices are so unstable. We can decide to grow onions or flowers if they have good rates in the market, but if everyone starts growing the same, then prices drop. Or if it rains too much, we have to throw everything away." It is because of such socionatural uncertainties that in Maharashtra, in the past 30 years, men started working more and more as wage laborers in industries and factories in nearby towns, to diversify the household's income; leaving it to women to perform most farming activities: what has been referred to as the "feminization of agriculture" (Deere, 2005; Agarwal, 2012; Tumbe, 2015; Pattnaik et al., 2017). COVID-19 and the related lockdown measures starkly revealed the fragility of this arrangement, as many agricultural laborers (mostly women) and wage workers (mostly men) could no longer travel and work in nearby farms and towns. In March, farmers did not know how long the lockdown would last, how long the possibilities of selling produce would remain constrained. This is why Vaishali and other farmers in her village felt it was too risky to invest in flowers cultivation like they had done in the previous years. They thus decided to cultivate larger portions of land with subsistence crops such as bajra (pearl millet), pulses, and peanuts. These involve much cheaper and secure investments in comparison to commercial crops such as flowers, as they can be consumed within the household and stored for a longer time. Conversely, flowers wither very quickly; they require more inputs in the form of pesticides and labor and they are more fragile to heavy monsoon. In such an uncertain situation the farmers did not want to take the risk of investing too much. Yet, at the same time, farmers did not want to stop cultivating commercial crops completely. Vaishali explained: "We know it is a risk, but we can't give up hope completely. What if markets open, and we do not have anything to sell? That's why we still have invested a little in flowers and onions. Even if we will get little in return that would already be good." Vaishali was right, planting some flowers turned out to be a worthy risk to take. In fact, before and during Diwali, an important Hindu festival that takes place in November, there was a shortage of flowers supply in nearby cities. Farmers like Vaishali earned up to three times higher rate than last year for the flowers they could sell.

Interestingly, our data suggests that, in India, decisions about changes in cropping patterns in times of COVID-19 were taken jointly by different family members within the household. Though market-related decisions are most often dealt with by the male members of the household (Agarwal, 2000; Mitra and Rao, 2019), the women farmers we talked to pointed out how they played a role in influencing these decisions. "My father-inlaw and my husband always listen to my opinion," said Meena, one of the women farmers we talked to regularly. At the same 
time, they also emphasized how they took some important decisions autonomously, without necessarily discussing them with their husbands. For instance, women famers realized the importance of cultivating more varieties of vegetables for the household. They noticed how the lockdown had changed their daily diet, which had become almost exclusively based on staple food such as wheat, rice, and pulses, and including very little vegetables, dairy and meat products. Hence, they came up with the idea of planting more and diverse vegetables in their farms, while trying to minimize expenses. Vaishali explained: "I did not discuss this much with my husband, I just plant vegetables along with other crops, between other crops, so I do not have to use additional fertilizers or water." This quote suggests how women farmers' knowledge informed specific forms of resilience, often geared toward care work: in this case, being able to maintain a varied nutritious diet, even when markets are close. In this direction, in order to support women farmers, the MAKAAM network set up an initiative to support their efforts in cultivating more vegetables while engaging in agroecological practices. Since August 2020, around 200 single women from across the state of Maharashtra started developing organic kitchen gardens, mostly sowing local varieties of seeds. Unfortunately, the monsoon season this year happened to be very long and intense: many kitchen gardens were destroyed in September and October. However, women remained hopeful. They continued taking care of their organic garden, using local resources, experiences, and knowledge in an attempt to improve their food security. In this regard, resilience emerges as self-reliance developed in light of local knowledge and traditional practices enhanced through the mediation of a network of activists and grassroot organizations (MAKAAM). This initiative emerged as a powerful one to strengthen the resilience of these single women farmers and agricultural laborers, especially of those who did not have access to government support schemes. It is one of many first steps to counteract women farmers'-and particularly single women farmers'-marginalization and exclusion: to transform power relations and enhance instead caring relations in the long-term, and thus beyond COVID-19.

In the Draa Valley in Morocco as well, young watermelons farmers adapted their cropping patterns during the lockdown months. The young male farmers are from local farming families: their background and farming experience, coupled with discussions among neighboring farmers on WhatsApp groups, helped them to make informed decisions about cropping patterns during the COVID-19 pandemic. Farmers know the volatility of the market for watermelons very well: "it's like a lottery: there is no guarantee," explained Ahmed, a young man who used to farm watermelons. For instance, everyone remembered 2018 as a disastrous year as the offer of watermelons significantly exceeded the demand and many farmers ended up with high debts. Consequently, after 2018, some farmers decided to minimize costs by reducing their expenses in agricultural inputs, including by reusing their water drip lines. Others planted watermelons on smaller areas and diversified their crops. Said, a young watermelon farmer told us: "I cultivate four hectares, sometimes three [of watermelons]. On the remaining land I plant some pineapples and another variety of melons." Their resilience is clearly informed by their past experience and knowledge. Although most of them, by adapting their farming practices made little or no profit this year, they did not accumulate additional debts. In the M'Zab valley, in Algeria, small-scale farmers also adapted their cropping patterns in relation to the challenges posed by the lockdown. As they could no longer go to specialized shops to buy agricultural inputs such as seeds of horticultural products imported from abroad and chemical fertilizers, many turned to traditional practices oriented toward agroecology. For instance, they started using manure as an organic fertilizer and sowing local seeds, such as local varieties of peppers, eggplants, and zucchini. Interestingly, the strong local demand for manure led to the emergence of a manure market in which livestock breeders in the area started to sell it to farmers in order to generate additional income.

Hence, for different small-scale farmers in the three case study countries, resilience in times of COVID-19 partly entailed trying to be more self-sufficient, minimizing investment risks and (re) using the locally available resources. It also meant drawing on diverse local knowledges of farming to respond to a multilayered crisis. Intrinsically, these practices and knowledges show how the ability to farm-grow food-provides an important source of resilience as it allows for a form of self-reliance by reducing dependence on market circuits-the very circuits that have become compromised because of the pandemic. Understanding this may inspire farmers to reconsider cropping patterns and farming practices in general in the long-term. As such, it emerges how different dimensions of crisis-like COVID-19-may trigger changes that give resilience a clearly transformative character, an input to rethink existing decision-making processes and the power relations that shape them.

\section{Collective Initiatives}

For others, more precisely better-off and thus more resourceful small-scale farmers, resilience during the lockdown involved engaging in new small-scale farming projects by reconnecting with the land of their ancestors and with traditional farming practices. In the M'Zab oases, in Algeria, several villages were repopulated during the lockdown as people who had migrated to nearby cities to work as wage workers or traders returned to their native villages when economic activities shut down. They took this as an opportunity to boost their agricultural activities and restore palm groves. Parents thought this was an interesting opportunity for their children to get to know the land of their ancestors and spend time outdoors, playing in the farms and using the irrigation basins as a swimming pool. Students too returned to their native villages due to the temporary closure of universities and offered their help in farming activities. However, the sudden increase in population and the boost of agricultural activities put pressure on the already scarce water resources of the valley. For this reason, in one of the oases of the M'Zab, Tahar, the Oumana El Sayl (traditional water guardian, working under the authority of the mosque and for the local association for the preservation of the environment) launched a campaign to restore the long-disrupted irrigation system in the village. In fact, in the M'Zab oases, since the eleventh century, local communities of farmers developed a circular irrigation system 
to capture, store and use the water of the rare flash floods (0-2 floods per year) in the valley. When flash floods happen, the water is channeled toward wells and traditional dams. This way it recharges the shallow groundwater aquifer and can be used for irrigation purposes. Yet, in the past decades, several recharge wells have been clogged by sediments and not maintained. The sediments affected the efficiency of the recharge and thus the groundwater level. The initiative of restoring the old irrigation system was organized through the traditional system of touiza, a mutual aid and cooperation system that characterize most community initiatives in the valley. Different communication channels, including social media, were used to raise funds for this maintenance work. With the money collected, the community restored 22 wells. According to a well digger, who we interviewed soon after the initiative started: "the groundwater level in the wells already increased by $5 \mathrm{~m}$." Different people contributed to this collective work in different ways, also making sure that the safety measures against the spread of COVID19 were respected. Local women started to sew face masks, supported by local associations that provided them with the raw material. Young men started health awareness campaigns related to the spread of COVID-19 both face-to-face and through social media. Resilience here, became a collective effort, based on the reparation and restoration of a dismissed infrastructure (Ftouhi et al., 2021). These practices of repairing can be seen as acts of care (Fisher and Tronto, 1990; Puig de la Bellacasa, 2012), as emerged clearly from the words of Houssem (president of the local association for the preservation of the environment): "The lockdown gave us the opportunity to take care of our community irrigation system." It represented an opportunity for local farmers to strengthen alliances among themselves and to enhance their agricultural activities to support their livelihoods and well-being during the lockdown but also in the long-term. Resilience here is rooted in knowledge inherited from ancestors: it is about reworking an infrastructure abandoned for many years and thus re-establishing a socionatural relation that was lost, or put aside for many years. In this regard, COVID-19 triggered practices that are not simply responses to a crisis, but work as long-term visions toward more sustainable and caring futures, involving both the human and the more-than-human world.

How resilience often involves and is enhanced through practices of care enhancing transformation became even more evident in light of other collective and individual initiatives emerging from our data. In the M'zab oases, several local associations coordinated support for migrants from other African countries who got stuck in Algeria during their journey to Europe. A food distribution campaign was organized during the month of Ramadan: women cooked rice and food baskets while men took charge of distributing them. Also, among the women laborers in Morocco some would engage in different forms of solidarity to be able to make ends meet. For instance, the costs of internet recharge cards would be shared so that their own children could follow online courses.

In Maharashtra, India, women farmers, activists and grassroot organizations that form the MAKAAM network, actively engaged in various forms of relief work to support women farmers and agricultural laborers, especially the most marginalized and those who did not have access to government support schemes. Among other initiatives, a fundraising campaign was organized to support women farmers to buy agricultural inputs for the next cropping season and distribute food and other essential items to those who were most in need. As mentioned before, the MAKAAM network also funded the construction of agroecological kitchen gardens to support women farmers' livelihood in the long term. Another initiative aimed at increasing women's access to work under the "Mahatma Gandhi Employment Guarantee Act (MGNREGA)." Through a women grassroots leadership development programme, the MAKAAM network encouraged women farmers and agricultural laborers to get together and demand work under this act, mobilizing at various administrative levels. In fact, as previously mentioned, almost none of the women we interviewed had access to this type of jobs during the lockdown months. As of November, many of these groups of women reported how they had succeeded in getting employment through this collective initiative, though often they had to deal with apathy by local administrations and sometimes corruption. This sheds light on how resilience can be mediated by civil society organizations and engaged (and caring) individuals and collectives (see also Agarwal, 2020). It also points out how yet another dimension of crisis like COVID-19, exacerbating existing dynamics of exclusion and marginalization triggered a long-term process to counteract those dynamics, to slowly transform an unequal and unfair distribution of resources.

\section{CONCLUDING REFLECTIONS}

Documenting the responses of the farmers and farm laborers to the pandemic and carefully listening to and sharing their experiences is our way to argue that there is value in focusing on the margins of the chain of food production (Béné, 2020; Clapp and Moseley, 2020; Timilsina et al., 2020; van der Ploeg, 2020)and specifically on what we can learn from those brave, capable and creative agricultural actors who inhabit these margins. By listening and documenting their voices we aim to engage with them, to express our solidarity and to provide space to "the unstable and constantly negotiated capacity to act and talk politically by those that usually 'do not count"' (GonzálezHidalgo and Zografos, 2019: 2). While writing this paper, we do not yet know how COVID-19 pandemic will shape the future, we do not know when we will be able to return to our field sites, to meet the farmers and farm laborers again. What we do know now is that there are ways to remain engaged, as researchers and activists, by staying in touch with the people who count for us, whom we care about, even from far away and in uncertain times.

Different challenges and multiple uncertainties characterize the everyday life of small-scale farmers and agricultural laborers in rural India, Morocco, and Algeria. COVID-19 and the lockdown that was imposed to attempt to reduce the spread of the virus added new challenges to the life of these agricultural actors. This resulted in various material implications, such as crops that had to be sold for a very 
cheap price or were left to rot on the farms. This impacted the income of farming households and many agricultural laborers could not find work. In this regard, COVID-19 revealed existing inequalities even more sharply as access to resources-such as land, money, technology-importantly determined how farmers could provide for themselves and their families, especially during the lockdown months. Through our intersectional lens it emerged that in Morocco and in India, women farmers and laborers were particularly hard hit by this pandemic. Significantly, landless women-often from lower class-and women who are socially neglected because of their matrimonial status (e.g., widowed, divorced, deserted women) had to deal with (re)newed forms of exclusion and oppression while their unpaid care work often increased enormously.

Despite this hardship, our data also shows that different agricultural actors came up with various inventive strategies to be resilient, to cope and provide for themselves and their families, responding to the new challenges faced during the lockdown. We approached resilience as something grounded and situated in the everyday-inspired among others by Cote and Nightingale (2012), MacKinnon and Derickson (2012), Welsh (2014), and Tozzi (2021), and that may involve persistence, adaptation but also transformation of socionatural configurations. With this approach, we aimed to emphasize the importance of paying specific attention to how power relations, but also existing knowledges and available resources shape how different actors experience and respond to multiple, entangled dimensions of crisis, and particularly-in this case-to the COVID-19 pandemic. Through our intersectional lens we documented how for less resourceful agricultural actors-such as landless womenresilience in times of COVID-19 meant nothing else but finding ways to survive: working secretly, looking for alternative sources of income, juggling the extra care work with earning income. Yet, in the case of more resourceful farmers, resilience was manifested in different, creative and inventive forms of adjusting to the situation. This included changes in farming practices such as cultivating crops they traditionally use for their own consumption rather than commercial crops. Others chose to reduce the expenses of farming by using local agricultural inputs, such as seeds and manure, or recycling old inputs (e.g., old drip lines for irrigation). Women farmers played a prominent role in influencing these decisions, highlighting how their knowledges and experiences emerged as fundamental in particularly troubled times. We also documented collective initiatives of repairing abandoned wells to give a new life to the traditional irrigation system to counteract water scarcity. We also presented initiatives that were mediated by the civil society and networks of solidarity and support built over the years. What emerged clearly is how all these inventive practices involved, and were motivated by forms and relations of care, among different actors but also toward the more-than-human world (see also Ticktin, 2020). In fact, they highlight the ability of different farmers to provide forand take care of-themselves and their household members, yet they also involve considerable work of repairing, reusing, and appreciating what is available in-situ (e.g., soil, water, seeds, manure, infrastructure). They suggest how small-scale farmers tried to transform their socionatures, by-among othersbecoming more self-sufficient, to rely more on existing, local resources while building new alliances and forms of solidarity, rather than being dependent on external agricultural inputs or on far-away markets and circulation chains.

We would like to end this paper by foregrounding how these narratives reiterated "from below" are important for rethinking the mainstream food production and distribution systems to give more space to much-needed alternatives such as food sovereignty, subsistence agriculture, decentralized markets and reviving agroecology approaches (van der Ploeg, 2020). They show the weaknesses of a system that overly depends on the mobility of goods, people and money, and they invite us to reconsider and appreciate the importance of local resources and diverse knowledges. This is of course not to suggest that the state should be de-responsibilized, or that resilience shall be a local, selfmanaged affair. Nor do we want to downplay the very real challenges and suffering the farmers are experiencing. Conversely, we argue, studying what resilience means and entails in a very grounded and situated manner may represent a starting point to shed light on existing marginalizations and exclusions and consequently to rethink (governmental and non-governmental) response programmes and support those most marginalized actors.

Coming back to the fundamental question of how resilience unfolds for different actors: this importantly relates to neoliberal economies that thrive on structural inequities and socionatural exploitation (MacKinnon and Derickson, 2012). In this regard, our feminist scholarly and activists' efforts urge us to focus and energize transformation rather than restoration of mainstream (neoliberalism-driven) economic, social, environmental dynamics, and configurations. Based on the joint learning from the experiences and practices of different small-scale farmers during the pandemic, we therefore argue that thinking with resilience should become an effort to unfold and enhance transformative practices toward more equitable and sustainable socionatures. This effort requires a vocabulary that captures what we observe and that is able to communicate its political implications. The concept of resilience can work as an umbrella term, as we have used it in this paper to describe responses to a multi-layered crisis. Yet, what resilience really means and entails needs to be carefully disentangled and described in a thick and careful manner. Conversely, an uncritical use of the concept of resilience risks to contribute to the idea that things should stay as they are, and that crisis are temporary, exceptional events. By choosing to mobilize the concept of intersectionality and focus on practices of care to disentangle what "being resilient" means in times of COVID-19 for different (groups of) people, we exposed the inequities embedded in the assumption that reality before COVID-19 was equitable or desirable for all and therefore should be simply restored. We hope that these insights and discussions can contribute to constructively engage with the different entangled socionatural challenges, uncertainties and marginalizations that agricultural actors face and bring about the lasting transformations this world needs post COVID-19. 


\section{DATA AVAILABILITY STATEMENT}

The datasets presented in this article are not publicly available for the respect and protection of the research subjects. Requests to access the datasets should be directed to the corresponding author, Irene Leonardelli: i.leonardelli@un-ihe.org.

\section{ETHICS STATEMENT}

The study was conducted in accordance with local legislations and institutional requirements.

\section{AUTHOR CONTRIBUTIONS}

LB, HF, and ZK conducted data collection in Morocco. SB, SK, and IL conducted data collection in India. MFH and MAS conducted data collection in Algeria. IL worked on the first draft of the manuscript together with LB, HF, SB, and MFH. JK-S, SK, and MZ importantly contributed to the editing of the manuscript. All authors contributed to the article and approved the submitted version.

\section{FUNDING}

The data presented in this paper has been collected in the context of the project Farming in times of crises: experiences, responses, and needs of smallholder farmers during the COVID19 pandemic funded by DUPC2: IHE Delft Partnership Programme for Water and Development. All authors are also involved in the T2SGS: Transformations to Groundwater Sustainability project funded as part of the Belmont Forum and NORFACE research programme Transformations to Sustainability (T2S).

\section{REFERENCES}

Adger, W. N. (2000). Social and ecological resilience: are they related? Prog. Hum. Geogr. 24, 347-364. doi: 10.1191/030913200701540465

Agarwal, B. (1992). The gender and environment debate: lessons from India. Feminist Stud. 18, 119-158. doi: 10.2307/3178217

Agarwal, B. (2000). Conceptualising environmental collection action: why gender matters. Cambridge J. Econ. 24, 283-310. doi: 10.1093/cje/24.3.283

Agarwal, B. (2003). Gender and land rights revisited: exploring new prospects via the state, family and market. J. Agrarian Change 3, 184-224. doi: 10.1111/1471-0366.00054

Agarwal, B. (2012). "Food security, productivity, and gender inequality," in The Oxford Handbook of Food, Politics, and Society, ed R. J. Herring (Oxford: Oxford University Press), 273-300.

Agarwal, B. (2020). Livelihoods in COVID times: gendered perils and new pathways in India. World Dev. 139:105312. doi: 10.1016/j.worlddev.2020.105312

Aït-Amara, H. (1999). "La transition de l'agriculture algérienne vers un régime de propriété individuelle et d'exploitation familiale," in Politiques foncières et aménagement des structures agricoles dans les pays méditerranéens : à la mémoire de Pierre Coulomb, eds A. M. Jouve, and N. Bouderbala. Conférences du Cours Spécialisé sur les Politiques Foncières et Aménagement des Structures Agricoles dans les Pays Méditerranéens, 1994/05/09-1994/06/05 (Montpellier; Adana: CIHEAM), 127-137. Available online at: http://om.ciheam.org/om/pdf/ c36/98400030.pdf
The work of IL has received funding from the European Union's Horizon 2020 research and innovation programme under the Marie Skłodowska-Curie Grant Agreement No. 764908. Research carried out by HF, ZK, and LB was further funded by the project Water-intensive agricultural growth in North-Africa: changing gendered farm identities and practices funded by DUPC2: IHE Delft Partnership Programme for Water and Development and the SALIDRAAjuj-01UU1906 project funded by the German Ministry of Education and Research (BMBF). Research carried out in Maharashtra, India is further funded through two other projects SOPPECOM is involved in: Building leadership of women farmers from suicide affected districts of Maharashtra supported by the Association for India's Development (AID), USA and by the COVID-19 relief support for women farmers in Maharashtra, supported by Centre for World Solidarity (CWS), India. Research carried out by MFH, MAS, and ZK was further funded by the project MASSIRE-Integrating multiple water sources and local institutions for enhanced food security in North Africa's hinterland by reinforcing agricultural \& rural innovation systems funded by IFAD.

\section{ACKNOWLEDGMENTS}

We would like to acknowledge and sincerely thank all the farmers and agricultural laborers we talked to in the three countries, who shared their stories and experiences with us. For what concerns the research carried out in India, we would like to acknowledge the support received by different members and partner organizations of the MAKAAM network, especially the Prakriti Resource Centre for Women and Development Nagpur, for facilitating many of our interviews with women farmers.

Akesbi, N. (2011). "Le Plan Maroc Vert: une analyse critique", in Questions d'économie Marocaine, ed Association Marocaine de Sciences Économiques (Rabat: Presses universitaires du Maroc), 9-48. Avaialble online at: http://www. amse.ma/doc/Questions\%20d'e\%CC\%81conomie\%202011.pdf

Ali, S., Asaria, M., and Stranges, S. (2020). COVID-19 and inequality: are we all in this together? Can. J. Public Health 111, 415-416. doi: 10.17269/s41997-020-00351-0

Bahn, K., Cohen, J., and van der Meulen Rodgers, Y. (2020). A feminist perspective on COVID-19 and the value of care work globally. Special issue: feminist frontiers special issue: gendered labor and work, even in pandemic times. Gender Work Org. 27, 695-699. doi: 10.1111/gwao. 12459

bell hooks, B. (2014). Ain't A Woman: Black Women and Feminism. New York, NY: Routledge.

Bell, M. M. (2005). The vitality of difference: systems theory, the environment, and the ghost of parsons. Soc. Nat. Resour. 18, 471-478. doi: 10.1080/08941920590924963

Béné, C. (2020). Resilience of local food systems and links to food security-a review of some important concepts in the context of COVID-19 and other shocks. Food Secur. 12, 805-822. doi: 10.1007/s12571-020-01076-1

Berger, E., Bossenbroek, L., Beermann, A. J., Schäfer, R. B., Znari, M., Riethmüller, S., et al. (2021). Social-ecological interactions in the Draa River Basin, southern Morocco: Towards nature conservation and human well-being using the IPBES framework. Sci. Total Environ. 769:144492. doi: 10.1016/j.scitotenv.2020.144492 
Bhat, S. (2016). "Deserted and widowed women's struggles for land and livelihood: a case from Maharashtra," in Land, Labour and Livelihoods, eds B. Fernandez, M. Gopal, M., and O. Ruthven (London: Palgrave Macmillan), 73-88. doi: 10.1007/978-3-319-40865-1

Bisson, J. (2003). Mythes et Réalités d’un Désert Convoité: le Sahara. Paris: L'Harmattan.

Bonelli, C. (2016). Erratum: eating one's worlds: on foods, metabolic writing and ethnographic humor. Subjectivity 9, 459-459. doi: 10.1057/sub.2016.7

Bossenbroek, L. (2016). Behind the veil of agricultural modernization: gendered dynamics of rural change in the Saiss, Morocco ( $\mathrm{PhD}$ thesis). Wageningen University. Available online at: https://library.wur.nl/WebQuery/wurpubs/ 507519

Bossenbroek, L. (2019). Les Ouvrières Agricoles Dans le Saïss au Maroc, Actrices de Changements Sociaux? Alternatives Rurales 7. Available online at: http:// alternatives-rurales.org/les- ouvrieres-agricoles-dans-le-saiss-au-marocactrices-de-changements-sociaux/

Bossenbroek, L., and Ftouhi, H. (2021). The plight of female agricultural wage workers in Morocco in times of the Covid-19 pandemic. Cahiers Agric.

Bossenbroek, L., Kuper, M., and Zwarteveen, M. (2016). "Sour grapes: the multiple enclosures of ground water in the region of the Saïs in Morocco," in Drip Irrigation: Untold Stories of Efficiency, Innovation and Development, Earthscan Studies in Water Resource Management, eds J. P. Venot, M. Kuper, and M. Zwarteveen (London: Routledge), 105-121.

Bossenbroek, L., van der Ploeg, J. D., and Zwarteveen, M. (2015). Broken dreams? Youth experiences of agrarian change in Morocco's Saïss region. Cahiers Agric. 24, 342-348. doi: 10.1684/agr.2015.0776

Bouchair, A. (2004). Decline of urban ecosystem of Mzab valley. Build. Environ. 39, 719-732. doi: 10.1016/j.buildenv.2003.12.001

Brand, F. S., and Jax, K. (2007). Focusing the meaning(s) of resilience: resilience as a descriptive concept and a boundary object. Ecol. Soc. 12:Article 23. doi: 10.5751/ES-02029-120123

Butler, J. (2020). "Human traces on the surfaces of the world," in ConTactos, eds D. Taylor and M. Godoy-Anativia. Available online at: https://contactos.tome. press/human-traces-on-the-surfaces-of-the-world/

Chakravarti, U. (1998). "Gender, caste and labour: ideological and material structure of widowhood," in Widows in India: Social Neglect and Public Action, ed M. A. Chen (New Delhi: Sage Publications).

Chen, M. A. (1998). Widows in India: Social Neglect and Public Action. New Delhi: Sage Publications.

Clapp, J., and Moseley, W. G. (2020). This food crisis is different: COVID-19 and the fragility of the neoliberal food security order. J. Peasant Stud. 47, 1-25. doi: $10.1080 / 03066150.2020 .1823838$

Cote, M. (2002). Des oasis aux zones de mise en valeur: l'étonnant renouveau de l'agriculture saharienne. Méditerranée 99, 5-14. doi: 10.3406/medit.2002.3253

Cote, M., and Nightingale, A. J. (2012). Resilience thinking meets social theory: situating social change in socio-ecological systems (SES) research. Prog. Hum. Geogr. 36, 475-489. doi: 10.1177/0309132511425708

Craig, L. (2020). Coronavirus, domestic labour and care: gendered roles locked down. J. Sociol. 56, 684-692. doi: 10.1177/1440783320942413

Crenshaw, K. (1989). Demarginalizing the intersection of race and sex: a black feminist critique of antidiscrimination doctrine, feminist theory, and antiracist politics. Univ. Chicago Legal Forum 1, 139-168.

Crow, B., and Sultana, F. (2002). Gender, class, and access to water: three cases in a poor and crowded delta. Soc. Nat. Resour. 15, 709-724. doi: $10.1080 / 08941920290069308$

Deere, C. D. (2005). The feminization of agriculture? Economic restructuring in rural Latin America. UNRISD Occasional Paper, 1. Available online at: https:// www.econstor.eu/handle/10419/148788

Domínguez Guzmán, C. (2019). Grandes narrativas, pequeños agricultores: explorando desbordes académicos en el caso de los excedentes de agua en el valle de Motupe, Perú. Estudios Atacameños 63, 365-381. doi: 10.22199/issn.0718-1043-2019-0029

Domínguez Guzmán, C., Verzijl, A., and Zwarteveen, M. (2017). Water footprints and 'pozas': conversations about practices and knowledges of water efficiency. Water 9:16. doi: 10.3390/w9010016

Elmhirst, R., and Resurreccion, B. (2008). "Gender, environment and natural resource management: new directions, new debates," in Gender and Natural
Resource Management: Livelihoods, Mobility and Interventions, eds B. P. Resurreccion and R. Elmhirst (London: Earthscan), 3-22.

Escobar, A., and Harcourt, W. (2005). "Introduction," in Women and the Politics of Place, eds A. Escobar and W. Harcourt (London: Zed Books), 1-19.

Fisher, B., and Tronto, J. (1990). "Toward a feminist theory of caring," in Circles of Care: Work and Identity in Women's Lives, eds E. Abel and M. Nelson (Albany, NY: SUNY Press), 35-62.

Food and Agriculture Organization (FAO) (2020). Family Farming Knowledge Platform. Algeria. Available online at: http://www.fao.org/family-farming/ countries/dza/en/ (accessed January 14, 2021).

Ftouhi, H., Kadiri, Z., Abdellaoui, E. H., and Bossenbroek, L. (2015). Partir et revenir au village. Mobilité non permanente des jeunes ruraux dans la région du Saïss (Maroc). Cahiers Agric. 24, 372-378. doi: 10.1684/agr. 2015.0780

Ftouhi, H., Saidani, M. A., Bossenbroek, L., Hamamouche, M. F., and Kadiri, Z. (2021). Entre vulnérabilité et résilience : le vécu de la pandémie de Covid-19 dans deux sociétés oasiennes au Maghreb. Cahiers Agric.

Gibson-Graham, J. K. (2014). Rethinking the economy with thick description and weak theory. Curr. Anthropol. 55, S147-S153. doi: 10.1086/676646

González-Hidalgo, M., and Zografos, C. (2019). Emotions, power, and environmental conflict: expanding the 'emotional turn' in political ecology. Prog. Hum. Geogr. 20, 235-255. doi: 10.1177/0309132518824644

Government of India (GoI) (2019). Agriculture Census 2015-16 (Phase-I). Agriculture Census Division Department of Agriculture; Co-operation and Farmers Welfare; Ministry of Agriculture and Farmers Welfare. Available online at: http://agcensus.nic.in/document/agcen1516/T1_ac_2015_16.pdf

Gururani, S. (2002). Forests of pleasure and pain: gendered practices of labor and livelihood in the forests of the Kumaon Himalayas, India. Gender Place Cult. J. Feminist Geogr. 9, 229-243. doi: 10.1080/0966369022000003842

Hamamouche, M. F., Kuper, M., Amichi, H., Lejarsc, C., and Ghodbanie, T. (2018). New reading of Saharan agricultural transformation: Continuities of ancient oases and their extensions (Algeria). World Dev. 107, 210-223. doi: 10.1016/j.worlddev.2018.02.026

Harris, L. M. (2006). Irrigation, gender, and social geographies of the changing waterscapes of southeastern Anatolia. Environ. Planning D Soc. Space 24, 187-213. doi: $10.1068 / \mathrm{d} 03 \mathrm{k}$

Hay, C. (2020). How privilege structures pandemic narratives. Feminism and philosophy special issue: feminist responses to COVID-19 and pandemics. Am. Philos. Assoc. Newslett. 20, 7-12. Available online at: https://cdn.ymaws. com/www.apaonline.org/resource/collection/D03EBDAB-82D7-4B28-B897C050FDC1ACB4/FeminismCovidSpecialIssueV20n1.pdf

Holt, A. (2010). Using the telephone for narrative interviewing: a research note. Qualitative Res. 10, 113-121. doi: 10.1177/1468794109348686

Ingalls, M. L., and Stedman, R. C. (2016). The power problematic: exploring the uncertain terrains of political ecology and the resilience framework. Ecol. Soc. 21:Article 6. doi: 10.5751/ES-08124-210106

Jordan, J. C. (2019). Deconstructing resilience: why gender and power matter in responding to climate stress in Bangladesh. Climate Dev. 11, 167-179. doi: 10.1080/17565529.2018.1442790

Joy, K. J., Kulkarni, S., Roth, D., and Zwarteveen, M. (2014). Repoliticising water governance: exploring water re-allocations in terms of justice. Local Environ. 19, 954-973. doi: 10.1080/13549839.2013. 870542

Karmaoui, A., Issam, I., Babqiqi, A., and Messouli, M. (2016). Analysis of the water supply-demand relationship in the Middle Draa Valley, Morocco, under climate change and socio-economic scenarios. J. Sci. Res. Rep. 9, 1-10. doi: $10.9734 / J S R R / 2016 / 21536$

Keck, M., and Sakdapolrak, P. (2013). What is social resilience? Lessons learned and ways forward. Erdkunde 67, 5-19. doi: 10.3112/erdkunde.2013.01.02

Krishna, S. and Kulkarni, S. (2018). "Gender and water: Why we need alternatives to alternative discourses," in India's Water Futures Emergent Ideas and Pathways, eds K. J. Joy, and S. Janakaraja (New York, NY: Routledge), 235-252. doi: $10.4324 / 9780429423529$

Kuchimanchi, B. R., Nazareth, D., Bendapudi, R., Awasthi, S., and D'Souza, M. (2019). Assessing differential vulnerability of communities in the agrarian context in two districts of Maharashtra, India. Climate Dev. 11, 918-929. doi: 10.1080/17565529.2019.1593815 
Kulkarni, H., and Shankar, P. V. (2014). Groundwater resources in India: an arena for diverse competition. Local Environ. 19, 990-1011. doi: 10.1080/13549839.2014.964192

Kulkarni, S. (2020). Locked in a crisis: concerns of rural women. Econ. Polit. Weekly 55:23. Available online at: https://www.epw.in/journal/2020/23/ commentary/locked-crisis.html

Kulkarni, S., and Bhat, S. (2010). Issues and concerns of deserted women in Maharashtra. Econ. Polit. Weekly XLV, 59-66. Available online at: https://www. jstor.org/stable/pdf/25742095.pdf

Kumar, R., Kumar Agrawal, N., Vijayshankar, P. S., and Vasavi, A. R. (2020). State of Rural and Agrarian India Report 2020. Rethinking Productivity and Populism Through Alternative Approaches. Network of Rural and Agrarian Studies. Available online at: http://www.ruralagrarianstudies.org/state-of-rural-andagrarian-india-report-2020/

Lahmadi, S., Bengouga, K., Maaoui, M., and Zeguerrou, R. (2016). Participation of rural women in agricultural activities in Algeria, the case of the commune of Maafa (South East Algeria). J. Algérien Régions Arides 13, 35-40. Available online at: https://www.asjp.cerist.dz/en/article/76112

Llamas, M. R., and Martínez-Santos, P. (2005). Intensive groundwater use: silent revolution and potential. J. Water Resour. Planning Manage. 131, 337-341. doi: 10.1061/(ASCE)0733-9496(2005)131:5(337)

Locke, C., Kantor, P., Morgan, M., and Kawarazuka, N. (2014). The ScoialEcological Systems Framework: Potential for Analysing Gender and Social Change? DEV Research Briefing, 10. Available online at: https://www. worldfishcenter.org/content/social-ecological-systems-framework-potentialanalysing-gender-and-social-change

Lupton, D. (2020). Doing Fieldwork in a Pandemic (Crowd-Sourced Document). Available online at: https://docs.google.com/document/d/ 1clGjGABB2h2qbduTgfqribHmog9B6P0NvMgVuiHZCl8/edit?ts=5e88ae0a\#

MacKinnon, D., and Derickson, K. D. (2012). From resilience to resourcefulness: a critique of resilience policy and activism. Prog. Hum. Geogr. 37, 253-270. doi: 10.1177/0309132512454775

Mahila Kisan Adhikar Manch (MAKAAM) (2020). Unlocking the Crisis Understanding Impacts of COVID-19 and Subsequent Lockdown on Single Women Farmers of Maharashtra. Available online at: http://makaam.in/events/ impact-of-covid-19-on-single-women-farmers-of-maharashtra-surveyreport/

Mitra, A., and Rao, N. (2019). Contract farming, ecological change and the transformations of reciprocal gendered social relations in Eastern India. $J$. Peasant Stud. 48, 436-457. doi: 10.1080/03066150.2019.1683000

Mohanty, B. B. (2005). 'We are like the living dead': farmer suicides in Maharashtra, western India. J. Peasant Stud. 32, 243-276. doi: 10.1080/03066150500094485

Mol, A., and Law, J. (2002). “Complexities: an introduction,” in Complexities: Social Studies of Knowledge Practices, eds A. Mol and J. Law (Durham, NC: Duke University Press), 1-22.

Mol, A., Moser, I., and Pols, J. (2010). "Care: putting practice into theory," in Care in Practice: On Tinkering in Clinics, Homes and Farms, eds A. Mol, I. Moser, and J. Pols (Berlin: Transkript Verlag), 7-27.

Nightingale, A. J. (2006). The nature of gender: work, gender, and environment. Environ. Plann. D Soci. Space 24, 165-185. doi: 10.1068/d01k

Nightingale, A. J. (2011). Bounding difference: intersectionality and the material production of gender, caste, class and environment in Nepal. Geoforum 42, 153-162. doi: 10.1016/j.geoforum.2010.03.004

O'Hara, P. (1998). Partners in Production: Women, Farm, and Family in Ireland. New York, NY: Berghahn Books.

Padhi, R. (2012). Those Who Did Not Die: Impact of the Agrarian Crisis on Women in Punjab. New Delhi: SAGE Publications.

Pattnaik, I., Lahiri-Dutt, K., Lockie, S., and Pritchard, B. (2017). The feminization of agriculture or the feminization of agrarian distress? Tracking the trajectory of women in agriculture in India. J. Asia Pacific Econ. 23, 138-155. doi: $10.1080 / 13547860.2017 .1394569$

Power, K. (2020). The COVID-19 pandemic has increased the care burden of women and families. Sustain. Sci. Prac. Policy 16, 67-73. doi: 10.1080/15487733.2020.1776561

Puig de la Bellacasa, M. (2012). 'Nothing comes without its world': thinking with care. Sociol. Rev. 60, 197-216. doi: 10.1111/j.1467-954X.2012.02070.x
Puig de la Bellacasa, M. (2017). Matters of Care: Speculative Ethics in More than Human Worlds. Minneapolis, MN: University of Minnesota Press.

Ramamurthy, P. (2003). Material consumers, fabricating subjects: perplexity, global connectivity discourses, and transnational feminist research. Cult. Anthropol. 18, 524-550. doi: 10.1525/can.2003.18.4.524

Ramamurthy, P. (2010). Why are men doing floral sex work? Gender, cultural reproduction, and the feminization of agriculture. Signs J. Women Cult. Soc. 35, 397-424. doi: 10.1086/605899

Sahay, G. R. (2010). "Globalization, liberalization and agrarian distress: a study of suicides among farmers in India," in Paper for VI. Global Labour University Conference (Berlin). Available online at: http://olumn.global-labouruniversity.org/fileadmin/GLU_conference_2010/papers/51._Globalisation_ Liberalisation_and_Agrarian_Distress.pdf

Salhi, Z. S. (2010). The Algerian feminist movement between nationalism, patriarchy and Islamism. Women's Stud. Int. Forum 33, 113-124. doi: 10.1016/j.wsif.2009.11.001

Shah, T. (2005). Groundwater and human development: challenges and opportunities in livelihoods and environment. Water Sci. Technol. 51, 27-37. doi: $10.2166 /$ wst.2005.0217

Simon, S., and Randalls, S. (2016). Geography, ontological politics and the resilient future. Dialogues in Human Geography. 6, 3-18. doi: $10.1177 / 2043820615624047$

Sultana, F. (2011). Suffering for water, suffering from water: emotional geographies of resource access, control and conflict. Geoforum 42, 163-172. doi: 10.1016/j.geoforum.2010.12.002

The World Bank (2019). Program Information Document (PID). Morocco Digital and Climate Smart Agriculture Program (P170419). Available online at: http:// documents1.worldbank.org/curated/en/648291567624827368/pdf/ConceptStage-Program-Information-Document-PID-Morocco-Digital-and-ClimateSmart-Agriculture-Program-P170419.pdf

Théroux-Séguin, J. (2016). "From empowerment to transformative leadership: intersectional analysis of women workers in the strawberry sector of Morocco," in Women in Agriculture Worldwide Key Issues and Practical Approaches, eds A. J. Fletcher and W. Kubik (Oxon; New York, NY: Routledge), 209-225.

Ticktin, M. (2020). Building a feminist commons in the time of COVID-19. Signs. Available online at: http://signsjournal.org/covid/ticktin/

Timilsina, B., Adhikari, N., Kafle, S., and Paudel, S. (2020). Addressing impact of COVID-19 post pandemic on farming and agricultural deeds. Asian J. Adv. Res. Rep. 11, 28-35. doi: 10.9734/ajarr/2020/v11i430272

Tozzi, A. (2021). An approach to pluralize socionatural resilience through assemblages. Progress Hum. Geogr. doi: 10.1177/03091325209 83471

Tronto, J. (2013). Caring Democracy: Markets, Equality, and Justice. New York, NY: New York University Press.

Tumbe, C. (2015). Missing men, migration and labour markets: evidence from India. Indian J. Labour Econ. 58, 245-267. doi: 10.1007/s41027-016-0017-4

van der Ploeg, J. D. (2020). From biomedical to politico-economic crisis: the food system in times of Covid-19. J. Peasant Stud. 47, 944-972. doi: 10.1080/03066150.2020.1794843

Verner, D., Treguer, D. O., Redwood, J., Christensen, J. H., Elbert, C., Konishi, Y., et al. (2018). Climate Variability, Drought, and Drought Management in Morocco's Agricultural Sector. World Bank. Available online at: http://documents1.worldbank.org/curated/en/353801538414553978/ pdf/130404-WP-P159851-Morocco-WEB.pdf doi: 10.1596/30603

Walker, B., Gunderson, L., Kinzig, A., Folke, C., Carpenter, S., and Schultz, L. (2006). A handful of heuristics and some propositions for understanding resilience in social-ecological systems. Ecol. Soc. 11:Article 13. doi: 10.5751/ES-01530-110113

Walker, J., and Cooper, M. (2011). Genealogies of resilience: from systems ecology to the political economy of crisis adaptation. Secur. Dial. 42, 143-160. doi: $10.1177 / 0967010611399616$

Welsh, M. (2014). Resilience and responsibility: governing uncertainty in a complex world. Geogr. J. 180, 15-26. doi: 10.1111/geoj.12012

Yadu, C. R., and Satheesha, B. (2016). Agrarian question in India: indications from NSSO's 70th round. Econ. Polit. Weekly 51, 20-23. Available online at: https:// www.epw.in/journal/2016/16/commentary/agrarian-question-india.html 
Yuval-Davis, N. (2006). Intersectionality and feminist politics. Euro. J. Women's Stud. 13, 193-209. doi: 10.1177/1350506806065752

Conflict of Interest: MFH and MAS were employed by the company Bureau d'Etudes, Consulting dans le domaine Agricole (ECA).

The remaining authors declare that the research was conducted in the absence of any commercial or financial relationships that could be construed as a potential conflict of interest.
Copyright (c) 2021 Leonardelli, Bossenbroek, Ftouhi, Kadiri, Bhat, Kulkarni, Hamamouche, Saidani, Zwarteveen and Kemerink-Seyoum. This is an open-access article distributed under the terms of the Creative Commons Attribution License (CC $B Y)$. The use, distribution or reproduction in other forums is permitted, provided the original author(s) and the copyright owner(s) are credited and that the original publication in this journal is cited, in accordance with accepted academic practice. No use, distribution or reproduction is permitted which does not comply with these terms. 